\title{
The Importance of Resilience and Flexibility of Entrepreneur Characters for Coping with a Crisis Situation. A Systematic Literature Review During Covid-19
}

\author{
Fawzia Alzahrani \\ School of Business, UMM-Al-Qura University \\ PO box 24373, Mecca 8WWG+P, Kingdom of Saudi Arabia \\ E-mail: fahzahrani@uqu.edu.sa
}

\begin{abstract}
What strategies do business leaders and aspiring entrepreneurs use to recover from adversity and start businesses in uncertain times? Things have changed recently when it comes to understanding what influences company decisions in challenging times. According to the findings of our recent research, certain human attributes are important to the success of entrepreneurs in the face of adversity. Resilience is also essential for entrepreneurs. Long-term economic development and increased private sector activity both depend on new enterprises, goods, services, and employment being created. Entrepreneurs are economic actors that provide the essential and desirable commodities and services as the lubricant that keeps the economy turning, whether they operate inside an existing organization or create a new firm. Entrepreneurs and aspiring entrepreneurs must: 1) participate in business development training to build their belief in their entrepreneurial resilience; 2) seek out networking events, special lectures, and mentoring opportunities to learn from others who have been resilient in difficult times; and 3) be active in their entrepreneurial pursuits, practice business acumen.

Keywords: Entrepreneurship Characteristic; personal characteristics; Business Resilience; Crisis management; Covid-19; SMEs; Entrepreneurial personality characteristics; Entrepreneurial Resilience; SMEs business survival; entrepreneurship mindset.
\end{abstract}

DOI: $10.7176 / \mathrm{EJBM} / 13-18-04$

Publication date:September $30^{\text {th }} 2021$

\section{Introduction}

The outbreak of unknown pneumonia was reported in December 2019 in Wuhan, Hubei Province of China. Search cases of pneumonia epidemiologically linked to the Sea Food wholesale in Hunan. However, the Covid19 pandemic was declared in March 2020 due to the fast-spreading nature of the virus and had taken up half of the world at that time. The virus has now spread to all parts of the world and has affected 220,563,227 people and caused deaths of more than 4,565,483 ("Weekly operational update on COVID-19 - 6 September 2021", 2021). The Covid-19 pandemic has spread irrespective of any boundary or conditions and has rendered the efforts of the government ineffective regardless of the location and level of power. The pandemic has developed an all-around economic and social crisis caused by a high level of uncertainty and recession. It has hit the small and medium-sized organizations and has developed new challenges and threats for such businesses as they had failed to prepare for this phase and lack investment in long-term resilience or developing a competitive edge. It has developed a Global Health crisis that is impacting industries of all sizes in nature and has disrupted the business processes, economic trades, and supply chain (Nicola et al., 2020).

The negative consequences of the pandemic have been found in all aspects of the social, psychological, political, and economic spheres. Apart from the disruptions identified with the Covid-19 pandemic, various new opportunities have been experienced in the market with new ideas and methods to stay resilient in the market as well as leading to a reversible repercussion to manage the crisis that is being faced by the world (Gregurec, Tomičić Furjan \& Tomičić-Pupek, 2021).

The businesses must develop a way to adapt to the new normal and quickly recover such that new opportunities are captured and a well-functioning market economy is developed especially for the start-ups and small and medium-sized organizations (SMEs) that are the important generators of income in the economy. Due to the special nature of the Covid-19 pandemic, there have been changes made in the specifics of management as well as the development of capital and the entrepreneur's personality that plays a vital role to develop such aspects which will be functional during this period (Monllor \& Murphy, 2017).

The lack of preparation for the external shocks or operating in new niches has now become extremely difficult for SMEs. A current systematic literature review will be conducted to identify the impact of resilience and flexibility skills of entrepreneurs and entrepreneurial forms that help in the recovery from the current Covid19 pandemic. The rest of the study will help in defining the findings, gaps, and conclusions of the study. 


\section{Methodology}

The method that is followed to conduct this research to fulfill the objectives of the study is through a systematic review of literature where the reviews will be used in the field of entrepreneurship. A limited number of reviews on the skills of entrepreneurs and the factors of entrepreneurship in the light of the Covid-19 pandemic were assessed effectively. Hence this systematic literature review was directed to develop evidence in terms of empirical studies and analysis of literature to review the importance of resilience and flexibility of entrepreneur characters to recover from the Covid-19 pandemic. This methodology would effectively develop a pattern to obtain results effectively as well as report research and implement the planning phase in the appropriate time.

\subsection{The Planning Phase:}

\subsubsection{Initial Literary Analysis and Research Question Formation:}

During the first stage of the review which is the planning phase, the researcher has reviewed the recent and the current literature that was available for the topic related to the skills of the entrepreneurs and the factors of entrepreneurial forms that help in the recovery from the current pandemic crisis. Also focusing on entrepreneurial resilience and the impact of the Covid-19 pandemic on the entrepreneurship levels and opportunities of the entrepreneurs during this situation.

\section{Entrepreneur and Entrepreneurship}

The entrepreneurship action and investigation of the development of social entrepreneurs' act as catalysts to organizations (Williams \& Shepherd, 2016). These entrepreneurs are leaders in their environment and can develop collective emotional energy in the favour of the creation of new institutional facilities which are effective for the communities that are impacted by disasters. In recent research, it is seen that entrepreneurs are the common people that have extraordinary thinking and planning skills and can face catastrophic situations effectively (Dutta, 2019).

\section{Characteristics of Entrepreneurs}

A number of research have been conducted to provide evidence regarding the attributes and characteristics of entrepreneurs in terms of social, psychological, or behavioural techniques that they apply to develop the personality of an entrepreneur (Roundy, 2019). The psychological aspect that predominantly focuses on the characteristics of entrepreneurs based on social and psychological aspects are mostly developed through the external forces that stimulate entrepreneurship behaviour. Considering entrepreneurship as a broad social environment that significantly affects one person or character is effective to develop the unique and dynamic nature of entrepreneurs who run the business single-handedly (Yunus, 2004).

Entrepreneurship is also important for developing a workforce that can focus on the innovations in structures of entrepreneurship. Hence entrepreneurs are important for the economic growth of a country and the development of innovative ideas for creations in order to create the importance of entrepreneurship in the field of administration, management, and economy. Entrepreneurs must develop characteristics with interdisciplinary aspects and our drivers of sociology, economics, and psychology (van Praag \& Versloot, 2007). Entrepreneurs are highly focused on developing a psychological perspective and are a primary personnel development where the variables in personality have significant importance in the development of entrepreneurship. Entrepreneurs have an important role to play in the management of the small and medium-size forms and identification of the future economic performance of an enterprise frequently discussed through practice and theory within an organization (Fine, Meng, Feldman \& Nevo, 2012).

Entrepreneurs focus on functioning within a competitive environment in dealing with threats that arise in a business from time to time by focusing on the ability to develop and change the external environment. Hence, a positive outlook is required by the entrepreneurs to move forward with optimism and confidence. Making efforts for the business through flexibility with the time schedules and operating business within the crisis will help in deciding the commitment towards goals. Also, entrepreneurs have the risk-taking ability as the personality and is an attribute that helps for thoughtfulness and face insecurities in a positive manner. Risk-taking helps to develop a height of middle decision-making and resource allocation as per the product choices and the market functioning and in wearing the standards and factors of decision making at the organizational level (Henshaw, ikegwuru \& Solomon, 2020). Hence, risk-taking is the articulation of a guarantee through a well-developed survival instinct for small and medium-sized organizations. Taking risks for the organization is the first and foremost activity that defines the unique characteristic of an entrepreneur.

Most of the researchers have developed various characteristics of entrepreneurs and those that make them successful. Entrepreneurship not only focuses on developing profits through uncertainty and risk but also creates innovation by introducing the measures to develop a workforce that can help entrepreneurs to emphasize such characteristics. Entrepreneurs have a risk-taking propensity and flexibility as well as openness towards risks and are positively relatable to the success of an entrepreneur (Antonio, Lanawati, Wiriana \& Christina, 2014).

This also includes three main characteristics of entrepreneurship to develop a locus of control, focusing on the need for achievements and taking risks to generate higher profits for the business (Fine, Meng, Feldman \& 
Nevo, 2012). The need for autonomy, creativity, self-confidence, trust, and initiative also drives characteristics of an entrepreneur as stated by several academic studies (Åstebro, Herz, Nanda \& Weber, 2014). These have been undertaken concerning medium and small-sized organizations and the response of entrepreneurs towards obstacles that affect the enterprise, especially at the time of the Covid-19 pandemic where a change is required for developing an attitude that is different and strong and personal characteristics that will help in overcoming the difficulty in crisis.

\section{Crises and Crisis Management}

Pieces of literature have defined the means of crisis and match with the divergent definitions where modern societies are facing the "unknown" Black Swans and Mega Crisis. Unforeseen situations such as the Covid-19 pandemic is a big factor in society and can also be regarded as a crisis (Doern, Williams \& Vorley, 2018).

Crises such as the health crisis have social, economic, and environmental effects as it becomes complex to manage. Businesses need to focus on adjusting to these crises to survive uncertain situations. The pandemics that were previously faced by the world had a global impact on the economy but had been significant and not as severe as the covid-19 situation where different views of life have been disrupted and restricted socially as well as geographically.

Crisis can occur in different forms of political, financial, technological, health, and organizational structures and is obvious to develop threats to the stakeholders. Table 1 provides a more detailed description of different types of crises and their causes in the environment (Ratten, 2020). Health crises such as coronavirus that was caused through diseases can be identified as pathogens and viruses that are difficult to trace (Thielsch, Röseler, Kirsch, Lamers \& Hertel, 2021). Political crises in World War 1 and World War 2 for the Iraq war have specific competitive tension between different nations that disrupts political peace and leads to unpredictable emergencies. Search prices, if associated with terrorist activities, can develop a situation of chaos and confusion such as the terrorist activity that was conducted on September 11.

Financial crisis also develops when the world faced a global crisis in 2008 that substantially changed the markets and the effect on consumer goods and the prices of lands and property. The technological crisis had occurred in the year 2000, a computer bug developer of an actual catastrophe developed various unusual circumstances (Williams, Gruber, Sutcliffe, Shepherd \& Zhao, 2017). Hence organizational crisis that can be identified through Lehman's brother's insolvency, can be linked to the specific contexts in the industry and can be regarded as a business crisis where team finances are highly affected through such crisis. Also, natural disasters tend to happen based on environmental factors such as tornadoes, floods, and other earth conditions that create issues for the people and may also lead to loss of life and property.

Table1. Comparison of crises and effects on entrepreneurship

\begin{tabular}{|l|l|l|}
\hline Type of crisis & Examples & Cause \\
\hline Health & Coronavirus(covid-19) & Virus \\
\hline Political & $9 / 11$ Iraq War, WW1, and WW2 & Disagreement between countries \\
\hline Financial & 2008 global financial crisis and 1930's great depression & Economic conditions \\
\hline Technological & 2000 bug & Changing to new technology \\
\hline Organizational & Lehman brothers & Human-made errors \\
\hline Natural & Floods, bushfires, and tornados & Environmental events \\
\hline
\end{tabular}

Crises that are developed through business are often regarded as big crises. Covid-19 pandemic, which has the following characteristics, has affected the business in the following ways (Thielsch, Röseler, Kirsch, Lamers \& Hertel, 2021):

1. Duration: a pandemic, due to its nature, has a long-term survival and it is not clear when the situation of uncertainty will come to an end.

2. Extent: A pandemic is a problem that supersedes any region and can affect any area of society. Hesitant to the pandemic is not limited to a specific country or region.

3. Varying dynamics: A pandemic especially begins through a series of situations that rapidly change and develop into an uncontrollable factor as it progresses (Sawalha, 2020). As a pandemic increases, the number of people that are affected also increases and develops dynamics that can be more controllable in the future. Concerning probabilities, it may become uncontrollable due to several situations such as the development of the second wave.

4. The novelty of threat: some of the threads are not easy to predict or understand and they partly remain theoretical.

5. Unclear political or legal framework: the legal environment is changing rapidly due to the development of official orders as well as the identification of basic rights of people that are being restricted in most environments and countries. In this situation, political responsibilities become unclear, and the assumption is made because of the extent of the pandemic and novelty combined with a highly changing environment from the beginning (He \& Harris, 2020). Hence it is obvious that the legal and regulatory framework is 
highly clear during the situation and leads to various types of problems for the people to understand such issues.

\section{Resilience and Crisis Management in Entrepreneurial Firms}

The literature on crisis management tends to take different perspectives and crisis management such as financial accounting and Management with effects on the entrepreneurship industry.

Entrepreneurship and crisis management helps in making development on the perspectives of prices that advances towards the streams of literature focusing on the aspects of sociology and business. The covid-19 pandemic has developed questions regarding how entrepreneurs can respond to this crisis as well as find solutions to deal with the effects of the crisis being much severe than the previous pandemics that have been faced by the world. It develops entrepreneurship as a social-economic performance to help society recuperate from the crisis. It aims to provide the capabilities of the entrepreneurs to function in high-risk and hostile environments and remove the stagnation of terrorism, political instabilities, and different kinds of unfavourable situations (DANES et al., 2009). Entrepreneurs must know how to deal with such a favourable environment and be better equipped to develop conditions in comparison to those that are non-entrepreneurs (Holland \& Shepherd, 2013).

The resilience of entrepreneurs is an essential concept that provides how a crisis can be managed by the ability to create a destructive event and conceptual aspects that help in the creation of this factor (Williams, Gruber, Sutcliffe, Shepherd \& Zhao, 2017). This review provides an overview to determine the trends and directions discussed, the existing gaps in the research, and determine which directions and gaps the current SLR will focus on. The first phase of the overview shows that entrepreneurs and start-ups must demonstrate resilience characteristics in crisis and disaster situations because they help overcome the volatility caused by market crises (Apostolopoulos, Newbery and Gkartzios, 2019; Ayala \& Manzano, 2014; Pal et al., 2014).

Resilience can be stated as the capacity of entrepreneurship to differentiate them from others and function effectively under the stress of adversity and uncertainty. Resilience in entrepreneurship has developed successful ventures for the entrepreneurs and focusing on the notion of resilience as the ability to bounce back from any kind of failure (Davidsson \& Gordon, 2016). This also focuses on developing a persistent nature towards any kind of crisis fees that can affect the organization (Shepherd, Patzelt \& Wolfe, 2011).

According to Pal et al. (2014), the entrepreneur's resilience quality enables him or her to adapt and survive in the face of difficult conditions and difficulties. In stressful situations, even the most difficult task can become the most delicate task. Resilient leaders are truly empathetic when making business decisions, empathizing with their employees, customers, and other parts of the ecosystem. On the other hand, resilient leaders must take a strong and wise stance to protect financial performance from the unalterable weakness of such changes (Folke et al., 2010). In an ecosystem context, resilience has three forms: (1) bouncing back to the socioeconomic state as before, (2) adaptation with new behaviours and forms albeit a fundamental replication of the prior socioeconomic structure, and (3) producing a radical change with an entirely new and different socioeconomic structure. Entrepreneurship may follow any of these three categories. It seems likely that post Covid-19 entrepreneurs will shape a new normal.

According to Doern (2009), the entrepreneurial characteristics of a person are often inborn and sometimes acquired. It is the inborn characteristics of a person which forces the right and timely response for a tough situation. It is the active duty of the entrepreneur to come up with new ideas for doing the business and incorporating innovation and creativity in whatever work they are doing. Strong-willed and tough entrepreneurs are not afraid of setbacks or even starting something new when needed. Grube \& Storr (2018), suggest that the entrepreneur must develop certain characteristics to actively respond to the changes and with equal or more innovation and creativity along with introducing more policies that will facilitate further growth of the organization. In addition, the pandemic situation has resulted in behavioural changes concerning entrepreneurship; however, entrepreneurs can combat this issue with the help of creativity and innovation. Entrepreneurial resilience and flexibility have helped organizations to effectively face the challenges presented by the pandemic (Branicki et al., 2017).

This entrepreneurial resilience is the ability to overcome setbacks and unexpected results while overcoming serious business problems. Entrepreneurs in the commercial enterprises as well as in the non-commercial sectors must come together to deal with the post-catastrophe ecology by humanely contributing towards society.

This review is conducted from a broad perspective to determine the trends and directions of the debate, existing research gaps, and determine which directions and gaps this SLR will focus on. Early research results indicate that entrepreneurs and entrepreneurial organizations must be resilient during emergencies or disasters to overcome turbulent market conditions through crisis scenarios (Apostolopoulos, N., Newbery, R., \& Gkartzios, M., 2019).

The key research issues of this research are as follows:

What role does the resilience of an entrepreneur play during crises? 


\subsubsection{Data Search:}

The steps involved in finding items in this study are defined in the protocol description given below.

- The researchers used highly reliable data sources and databases and found that the articles were downloaded and searched using the Scopus database and Google Scholar.

- Since this study also focused on the crisis management issues in entrepreneurship it also covered some resilience and, the researchers focused on papers published in the last two 2 years.

- Researchers used the advanced search options of the Scopus and Google Scholar databases to narrow their search by year, with popular publishers such as Emerald and Springer.

- The researchers used several search terms designed to find all relevant research. This mainly includes "Entrepreneurship Characteristic; personal characteristics; Business Resilience; Crisis management; Covid-19; SMEs; Entrepreneurial personality characteristics; Entrepreneurial Resilience; SMEs business survival; entrepreneurship mindset.

- Both empirical and overview kind studies papers have been included, however, no books, chapters or online sources have been included

\subsubsection{Inclusion Criteria Plan}

The researcher deliberates to experiment with the quest and extract sixty-five articles. After this, the researcher aimed to, in addition, display them primarily based totally on their identity and the indexed key phrases within the summary. This will permit the researcher to discard any papers that aren't centered on the primary topic of the study, then evaluate the titles and key phrases of the discarded articles to rescan and read the summary of the discarded articles to make certain that no article of significance is left out. The subsequent step might be that reads through the abstracts of the chosen articles and discards any irrelevant paper

\subsection{The Implementation Phase:}

This review provides an overview to determine the trends and directions discussed, the existing gaps in the research, and determine which directions and gaps the current SLR will focus on. The first phase of the overview shows that entrepreneurs and startups must demonstrate resilient characteristics in crisis and disaster situations because they help overcome the volatility caused by market crises

\section{Findings}

\subsection{Descriptive Findings:}

In this section, the researcher will include details about the research papers that were included in this study. Table 2 given below shows the authors, titles, and year of publishing of the 13 included articles in this study as well as the type and journal of each paper.

Table 2: Included Papers in SLR

\begin{tabular}{|c|c|c|c|}
\hline Authors & Paper Name & Journal & Year \\
\hline $\begin{array}{l}\text { May Portuguez Castro, } \\
\text { Marcela Georgina Gómez } \\
\text { Zermeño }\end{array}$ & $\begin{array}{l}\text { Being an entrepreneur post-COVID-19 } \\
\text { - resilience in times of crisis: a } \\
\text { systematic literature review }\end{array}$ & $\begin{array}{l}\text { Journal of Entrepreneurship } \\
\text { in Emerging Economies }\end{array}$ & 2020 \\
\hline $\begin{array}{l}\text { Muhammad Hidayat, Fitriani } \\
\text { Latief, Dara Ayu Nianti, } \\
\text { Shandra Bahasoan, Andi } \\
\text { Widiawati }\end{array}$ & $\begin{array}{l}\text { Factors Influencing Resilience of Micro } \\
\text { Small } \\
\text { and Medium Entrepreneur (MSME) } \\
\text { during COVID } 19 \text { Outbreak in South } \\
\text { Sulawesi } \\
\text { Province Indonesia }\end{array}$ & $\begin{array}{l}\text { TEST (Engineering } \\
\text { \&Management) Journal. }\end{array}$ & 2020 \\
\hline $\begin{array}{l}\text { Suresh Chandra Akula } \\
\text { Pritpal Singh }\end{array}$ & $\begin{array}{l}\text { Impact of COVID } 19 \text { on } \\
\text { Entrepreneurship: A Systematic } \\
\text { Review }\end{array}$ & $\begin{array}{l}\text { INTERNATIONAL } \\
\text { JOURNAL OF eBUSINESS } \\
\text { and eGOVERNMENT } \\
\text { STUDIES }\end{array}$ & 2021 \\
\hline $\begin{array}{l}\text { Andreas Kuckertz, Leif } \\
\text { Brandle, Anja Gaudig, } \\
\text { Sebastian Hinderer, Carlos } \\
\text { Arturo Morales Reyes, Alicia } \\
\text { Prochotta, Kathrin M. } \\
\text { Steinbrink, Elisabeth S.C. } \\
\text { Berger }\end{array}$ & $\begin{array}{l}\text { Startups in times of crisis }- \text { A rapid } \\
\text { response to the } \\
\text { COVID-19 pandemic }\end{array}$ & $\begin{array}{l}\text { Journal of Business } \\
\text { Venturing Insights }\end{array}$ & 2020 \\
\hline $\begin{array}{l}\text { Titien Agustina, Marisi } \\
\text { Butarbutar, Rinto Alexandro, } \\
\text { Anthonius Karsudjono }\end{array}$ & $\begin{array}{l}\text { The Key to MSMEs Ability to Survive } \\
\text { the Covid-19 Pandemic (Case studies } \\
\text { in Indonesia) }\end{array}$ & $\begin{array}{l}\text { Turkish Online Journal of } \\
\text { Qualitative Inquiry (TOJQI) }\end{array}$ & 2021 \\
\hline
\end{tabular}




\begin{tabular}{|c|c|c|c|}
\hline Authors & Paper Name & Journal & Year \\
\hline $\begin{array}{l}\text { Dalili Izni Shafie, Salmi Mohd } \\
\text { Isa }\end{array}$ & $\begin{array}{l}\text { Entrepreneur Resilience: How Do } \\
\text { Entrepreneurial Self-Efficacy and Basic } \\
\text { Psychological Needs Influence It? The } \\
\text { Effect of COVID-19 on Malaysia's } \\
\text { Small and Medium Enterprises }\end{array}$ & Jurnal Intelek & 2021 \\
\hline Esha Thukral & $\begin{array}{l}\text { COVID-19: Small and medium } \\
\text { enterprises challenges and responses } \\
\text { with creativity, innovation, and } \\
\text { entrepreneurship }\end{array}$ & John Wiley \& Sons Ltd. & 2021 \\
\hline $\begin{array}{l}\text { Yipeng Liu and Fabian Jintae } \\
\text { Froese } 3\end{array}$ & $\begin{array}{l}\text { Crisis management, global challenges, } \\
\text { and sustainable } \\
\text { development from an Asian perspective }\end{array}$ & $\begin{array}{l}\text { Asian Business \& } \\
\text { Management }\end{array}$ & 2021 \\
\hline Ihab Hanna Sawalha & $\begin{array}{l}\text { A contemporary perspective on the } \\
\text { disaster management cycle }\end{array}$ & Emerald Publishing Limited & 2020 \\
\hline $\begin{array}{l}\text { Nikolaos Apostolopoulos, } \\
\text { Vanessa Ratten, Stavros } \\
\text { Stavroyiannis, Ilias Makris, } \\
\text { Sotiris Apostolopoulos, } \\
\text { Panagiotis Liargovas } \\
\end{array}$ & $\begin{array}{l}\text { Rural health enterprises in the EU } \\
\text { context: a systematic literature review } \\
\text { and research agenda }\end{array}$ & $\begin{array}{l}\text { Journal of Enterprising } \\
\text { Communities: People and } \\
\text { Places in the Global } \\
\text { Economy }\end{array}$ & 2020 \\
\hline $\begin{array}{l}\text { Hemad Hamedi and Amir } \\
\text { Mehdiabadi }\end{array}$ & $\begin{array}{l}\text { Entrepreneurship resilience and } \\
\text { Iranian organizations: application } \\
\text { of the fuzzy DANP technique }\end{array}$ & $\begin{array}{l}\text { Asia Pacific Journal of } \\
\text { Innovation and } \\
\text { Entrepreneurship }\end{array}$ & 2020 \\
\hline Shepherd, Dean A. & $\begin{array}{l}\text { COVID } 19 \text { and entrepreneurship: Time } \\
\text { to pivot? }\end{array}$ & $\begin{array}{l}\text { Journal of Management } \\
\text { Studies }\end{array}$ & 2020 \\
\hline $\begin{array}{l}\text { Alex Maritz, } \\
\text { Aron Perenyi, Gerrit de Waal } \\
\text { and Christoph Buck }\end{array}$ & $\begin{array}{l}\text { Entrepreneurship as the Unsung Hero } \\
\text { during the Current COVID-19 } \\
\text { Economic Crisis: Australian } \\
\text { Perspectives }\end{array}$ & Sustainability & 2020 \\
\hline
\end{tabular}

Table 3: The author's main views on the impact of the crisis on entrepreneurship

\begin{tabular}{|l|l|}
\hline Author & Point of View \\
\hline $\begin{array}{l}\text { May Pómez Zermeño } \\
\text { Muhammad Hidayat, Fitriani Latief, } \\
\text { AndiWidiawati }\end{array}$ & $\begin{array}{l}\text { The importance of resilience in order to improve } \\
\text { entrepreneurship training programmes. }\end{array}$ \\
\hline $\begin{array}{l}\text { Suresh Chandra Akula } \\
\text { Pritpal Singh }\end{array}$ & $\begin{array}{l}\text { Business resilience is very strong Affected by entrepreneurship } \\
\text { Economic entities have a strong entrepreneurial spirit Therefore } \\
\text { entrepreneurs can face various situations Fight for survival Face } \\
\text { challenges ahead of time. }\end{array}$ \\
\hline $\begin{array}{l}\text { Andreas Kuckertz, Leif Br€andle, Anja } \\
\text { Gaudig, Sebastian Hinderer, Carlos } \\
\text { Arturo Morales Reyes, Alicia Prochotta, } \\
\text { Kathrin M. Steinbrink, Elisabeth S.C. Berger }\end{array}$ & $\begin{array}{l}\text { Resilience, flexibility, perseverance, and change readiness as } \\
\text { the main characteristics of the entrepreneurs that have helped } \\
\text { them use the opportunities provided by the crisis. }\end{array}$ \\
\hline $\begin{array}{l}\text { Titien AgustinaMarisi ButarbutarRinto } \\
\text { AlexandroRinto Alexandro Anthonius } \\
\text { Karsudjono Anthonius Karsudjono }\end{array}$ & $\begin{array}{l}\text { Entrepreneurs responding to the COVID19 crisis are using } \\
\text { triggered by the crisis into resilience. }\end{array}$ \\
\hline Dalili Izni Shafie, Salmi Mohd Isa & $\begin{array}{l}\text { Resilient personal characteristics in a person will be able to } \\
\text { encourage the birth of the correct response to rising from } \\
\text { problems. }\end{array}$ \\
\hline Esha Thukral & $\begin{array}{l}\text { Fulfillment with basic psychological requirements may have a } \\
\text { major impact on the link between entrepreneurial self-efficacy } \\
\text { and entrepreneurial resilience. }\end{array}$ \\
\hline Yipeng Liu, Fabian Jintae Froese3 & $\begin{array}{l}\text { The capability to respond to face crisis depends on the } \\
\text { entrepreneur's resilience to continue with creative and } \\
\text { innovative ideas. }\end{array}$ \\
\hline $\begin{array}{l}\text { Increasingly, cultivating appropriate crisis-coping strategies and } \\
\text { building resilience is essential for individuals, organizations, } \\
\text { and society to thrive in an age of uncertainties. }\end{array}$ \\
\hline
\end{tabular}




\begin{tabular}{|l|l|}
\hline Author & Point of View \\
\hline Ihab Hanna Sawalha & $\begin{array}{l}\text { Flexibility in organizations can come from the skills and } \\
\text { capabilities of entrepreneurs that can lead to the fighting of the } \\
\text { crisis better }\end{array}$ \\
\hline $\begin{array}{l}\text { Nikolaos Apostolopoulos, Vanessa Ratten, } \\
\text { Stavros Stavroyiannis, Ilias Makris, Sotiris } \\
\text { Apostolopoulos, Panagiotis Liargovas }\end{array}$ & $\begin{array}{l}\text { Flexibility of entrepreneurial and small businesses allowed } \\
\text { them to confront the challenges presented by the COVID-19. }\end{array}$ \\
\hline Hemad Hamedi and Amir Mehdiabadi & $\begin{array}{l}\text { Many organizations and companies face many problems and } \\
\text { overcoming crisis situations and organizational resilience is one } \\
\text { of the most important things in life, rehabilitation, or } \\
\text { development. }\end{array}$ \\
\hline Shepherd, Dean A. & $\begin{array}{l}\text { Attention to entrepreneurial mechanisms, capable of providing } \\
\text { balance in around a new future; the focus on society's } \\
\text { resilience. }\end{array}$ \\
\hline $\begin{array}{l}\text { Alex Maritz1, *, } \\
\text { Aron Perenyi2, Gerrit de Waal3and Christoph } \\
\text { Buck4,5 }\end{array}$ & $\begin{array}{l}\text { Further research is needed, especially in light of context and } \\
\text { empirical results. During the current COVID-19 economic } \\
\text { crisis, that entrepreneurship may be the unsung hero. }\end{array}$ \\
\hline
\end{tabular}

\subsection{Systematic Review findings}

According to Razak et al. (2020), the global pandemic has shut the whole world in their houses and business, education, tourism; everything has been put to hold. To deal with this crisis organizations and companies all over the world are coming up with numerous innovative ideas to get the work done. Resilience is one of the most important ideas, rehabilitation, or development (Hamedi \& Mehdiabadi, 2020). The firms and organizations have come up with the idea of work from home, with the help of technology and communication. Here, it can be stated that resilience has become an entrepreneurial skill in the modern era (Castro \& Zermeño, 2020). Although technology has helped the work to be carried on smoothly, managing the business online and keeping the employees motivated in such a difficult situation is the real task at hand. While many businesses were forced to shut down due to the pandemic, only a few of the businesses saw this as an opportunity to improve and develop. It is the sheer willpower, resilience, and flexibility, change, the readiness of the entrepreneurs who saw the opportunity and grabbed it right away. Shepherd (2020), Kuckertz, A., Brändle, L., Gaudin, A., Hinderer, S., Reyes, C. A. M., Prochotta, A., ... \& Berger, E. S. (2020), and Akula \& Singh (2021), opine that a motivated and dedicated entrepreneur is the key factor of a successful organization. Entrepreneurs who have successfully sustained the business in such a difficult and trying situation have actively gained more confidence, feel more positive and reassured. The crisis has helped the entrepreneurs to push their boundaries and go the extra distance, to get the work done. In this regard, it is to be noted that the risk-taking ability of the entrepreneurs helps entrepreneurial ventures to survive.

The MSMEs are highly dependent on the human resource department who help the business to run smoothly and systematically. Shafie \& Isa (2021) suggest that it is important to build a resilient attitude in entrepreneurs, as it is more feasible, and helps them get through any crisis. The entrepreneurs can contribute towards the maintenance of the flow of goods and services, boosting the morale of the community and other businesses, and contribute towards the continuity of the business. Hidayat, M., Latief, F., Nianti, D. A., Bahasoan, S., \& Widiawati, A. (2020) demonstrated that business resilience is very strong. Affected by entrepreneurship, economic entities have a strong entrepreneurial spirit. Therefore, entrepreneurs can face various situations fight for survival to face challenges ahead of time.

Moreover, the study by Agustina, T., Butarbutar, M., Sherly, R. A., \& Karsudjono, A. J. (2021) in an age of uncertainties, it is important for every individual to build and cultivate proper strategies to cope up with the crisis. Even organizations and society, in general, must develop resilience to survive in such difficult times. Entrepreneurs these days are comparatively resilient given their experiences in various uncertain environments, adversity, and informal organizations settings. Hence, the resilience of the entrepreneurs makes the SMEs resilient which is very different from the practices of the larger firms and organizations. Liu \& Froese (2020), hold the view that not only resilience, but even flexibility is also an essential factor for an organization to run successfully. Therefore, the skills of an entrepreneur can help make the organization flexible which in turn will help them overcome and face any crisis. This stands true to the situation of the Covid-19 pandemic. An entrepreneur needs to have adaptability and flexibility to harness their innovative and creative aspects as well (Apostolopoulos et al., 2020). Challenges and uncertainties are a part of running a business and it is the role of the entrepreneurs to face them with resilience. Here, it can be added that the role of the entrepreneurs is significant in overcoming the economic crisis due to Covid 19 (Maritz, Perenyi, De Waal, \& Buck, 2020). The entrepreneurs are not only responsible for effectively running the organization, but they are also responsible for keeping their employees motivated and resilient in trying situations as well (Apostolopoulos et al., 2020). 
Entrepreneurs must be open to change and ready to grab any opportunity that comes in the way. Sawalha (2019) opines that the global pandemic has taken a massive toll on the economic market and has forced numerous businesses to shut down. However, resilient entrepreneurs have seen this as an opportunity to test their limits and push their boundaries to grow and develop their organizations even further. Finally, Thukral, E. (2021) emphasized that the ability to respond to crises depends on the entrepreneur's ability to adapt to creative and innovative ideas.

\section{Discussion: Looking at the Gaps and New directions}

The current research has found a number of gaps in the current studies on resilience, entrepreneurship, and crisis management, at least in the scope of the analyzed publications. There was a gap in the current literature addressed by this review study, which connected crises with resilience and entrepreneurship by looking at how entrepreneurs contribute to the rehabilitation and reorganization of their communities following adversities, crises, or disaster occurrences. However, the review found several gaps and suggested areas for future research, which was then discussed. However, prior empirical research has been inconclusive because it is still unclear what entrepreneurial resilience means in general and which possible elements help individuals develop and improve this skill. As a result, more research is required on the numerous resources available for enhancing resilience. Institutes that promote entrepreneurial education should take advantage of this opportunity to create a space where resilience education can be promoted among entrepreneurs so that they see it as a critical attribute and use it to encourage resilience among entrepreneurs

Current research focuses on the entrepreneurial skills and agility that firms and individuals are expected to have, rather than the procedures for dealing with disasters and crises, as demonstrated by COVID-19. In addition, entrepreneurs' coping techniques and learning priorities have largely been overlooked. COVID-19 has given entrepreneurs the tools they need to respond and overcome the dangers and obstacles they face because of adversity. This pandemic's size necessitates research into the variables that started the disruptions, as well as an exciting area of research into methods and qualities that could influence and regulate the underlying causes. Due to the severity of the crisis situations, a useful framework for guiding the recovery process has been provided by resilience. Even still, prior empirical studies have come up empty because it is still unknown what entrepreneurial resiliency actually is. Also, entrepreneurs should pay attention to the lessons learned from previous occurrences and realize the imperial necessity of adapting to new circumstances to minimize future repercussions. have acknowledged that entrepreneurship is essential for regional and local development. However, there is a need for the acknowledgment of resilience as a key characteristic of entrepreneurs and needs to be promoted through entrepreneurial education to increase the preparedness in the people.

\section{Conclusion: Summary, Implications, and Limitations}

It is clear from the above discussion that entrepreneurial resilience plays an important role during a crisis. Entrepreneurs who have successfully overcome the crisis have developed more confidence and a positive attitude towards obstacles. A trying situation brings out the best from the entrepreneurs as it forces them to make effective and right decisions to face the challenge although facing the crisis is not the end of the part of the entrepreneur. In order to face any future obstacles, the entrepreneur must develop strategies and policies beforehand and build the confidence of the employees too. Resilience, adaptability, and flexibility are key characteristics of an entrepreneur, which will help an organization to build the same characteristics as well.

\section{References}

Agustina, T., Butarbutar, M., Sherly, R. A., \& Karsudjono, A. J. (2021) The Key to MSMEs Ability to Survive the Covid-19 Pandemic (Case studies in Indonesia).

Antonio, T., Lanawati, S., Wiriana, T., \& Christina, L. (2014). Correlations Creativity, Intelligence, Personality, and Entrepreneurship Achievement. Procedia - Social and Behavioral Sciences, 115, 251- 257. doi: 10.1016/j.sbspro.2014.02.433

Åstebro, T., Herz, H., Nanda, R., \& Weber, R. (2014). Seeking the Roots of Entrepreneurship: Insights from Behavioral Economics. Journal Of Economic Perspectives, 28(3), 49-70. doi: 10.1257/jep.28.3.49

Akula, S. C., \& Singh, P. (2021). IMPACT OF COVID 19 ON ENTREPRENEURSHIP: A SYSTEMETIC LITERATURE REVIEW. International Journal of eBusiness and eGovernment Studies, 13(1), 1-22.

Apostolopoulos, N., Ratten, V., Stavroyiannis, S., Makris, I., Apostolopoulos, S., \& Liargovas, P. (2008). Rural health enterprises in the EU context: a systematic literature review and research agenda. Journal of Enterprising Communities: People and Places in the Global Economy.

Apostolopoulos, N., Newbery, R., \& Gkartzios, M. (2019). Social enterprise and community resilience: Examining a Greek response to turbulent times. Journal of Rural studies, 70, 215-224.

Castro, M. P., \& Zermeño, M. G. G. (2020). Being an entrepreneur post-COVID-19-resilience in times of crisis: a systematic literature review. Journal of Entrepreneurship in Emerging Economies. 
Doern, R. (2009). Investigating barriers to SME growth and development in transition environments: A critique and suggestions for developing the methodology. International Small Business Journal, 27(3), 275-305

Doern, R. (2021). Knocked down but not out and fighting to go the distance: small business responses to an unfolding crisis in the initial impact period. Journal of Business Venturing Insights, 15, e00221.

Doern, R., Williams, N., \& Vorley, T. (2019). Special issue on entrepreneurship and crises: business as usual? An introduction and review of the literature. Entrepreneurship \& Regional Development, 31(5-6), 400-412. doi: 10.1080/08985626.2018.1541590

Dutta, S. (2019). Seeing parochially and acting locally: Social exposure, problem identification and social entrepreneurship. Journal Of Business Venturing, 34(6), 105942. doi: 10.1016/j.jbusvent.2019.06.003

Danes, S., Lee, J., Amarapurkar, S., Stafford, K., Haynes, G., \& Brewton, K. (2009). Determinants Of Family Business Resilience After a Natural Disaster By Gender Of Business Owner. Journal Of Developmental Entrepreneurship, 14(04), 333-354. doi: 10.1142/s1084946709001351

Davidsson, P., \& Gordon, S. (2016). Much Ado about Nothing? The Surprising Persistence of Nascent Entrepreneurs through Macroeconomic Crisis. Entrepreneurship Theory and Practice, 40, 915 - 941.

Fine, S., Meng, H., Feldman, G., \& Nevo, B. (2012). Psychological Predictors of Successful Entrepreneurship in China: An Empirical Study. The International Journal of Management, 29, 279.

Folke, C., Carpenter, S., Walker, B., Scheffer, M., Chapin, T., \& Rockström, J. (2010). Resilience Thinking: Integrating Resilience, Adaptability and Transformability. Retrieved 20 September 2021, from http://www.ecologyandsociety.org/vol15/iss4/art20/

Gregurec, I., Tomičić Furjan, M., \& Tomičić-Pupek, K. (2021). The Impact of COVID-19 on Sustainable Business Models in SMEs. Sustainability, 13(3), 1098. doi: 10.3390/su13031098

Hamedi, H., \& Mehdiabadi, A. (2020). Entrepreneurship resilience and Iranian organizations: application of the fuzzy DANP technique. Asia Pacific Journal of Innovation and Entrepreneurship.

Hidayat, M., Latief, F., Nianti, D. A., Bahasoan, S., \& Widiawati, A. (2020). Factors influencing resilience of micro small and medium entrepreneur (MSME) during COVID 19 outbreak in South Sulawesi Province Indonesia

Holland, D. V., \& Shepherd, D. A. (2011). Deciding to Persist: Adversity, Values, and Entrepreneurs' Decision Policies. Entrepreneurship Theory and Practice, 37(2), 331-358.

Henshaw, A., ikegwuru, m., \& Solomon, W. (2020). Entrepreneurial Orientation and Marketing Performance of SMEs in Rivers State of Nigeria, 13(01).

He, H., \& Harris, L. (2020). The impact of Covid-19 pandemic on corporate social responsibility and marketing philosophy. Journal Of Business Research, 116, 176-182. doi: 10.1016/j.jbusres.2020.05.030

Holland, D., \& Shepherd, D. (2013). Deciding to Persist: Adversity, Values, and Entrepreneurs' Decision Policies. Entrepreneurship Theory and Practice, 37(2), 331-358. doi: 10.1111/j.1540-6520.2011.00468.x

Kuckertz, A., Brändle, L., Gaudig, A., Hinderer, S., Reyes, C. A. M., Prochotta, A., ... \& Berger, E. S. (2020). Startups in times of crisis-A rapid response to the COVID-19 pandemic. Journal of Business Venturing Insights, 13, e00169.

Liu, Y., \& Froese, F. J. (2020). Crisis management, global challenges, and sustainable development from an Asian perspective.

Maritz, A., Perenyi, A., De Waal, G., \& Buck, C. (2020). Entrepreneurship as the unsung hero during the current COVID-19 economic crisis: Australian perspectives. Sustainability, 12(11), 4612.

Monllor, J., \& Murphy, P. (2017). Natural disasters, entrepreneurship, and creation after destruction. International Journal of Entrepreneurial Behavior \& Research,23(4), 618-637. doi: 10.1108/ijebr-02-2016-0050

Nicola, M., Alsafi, Z., Sohrabi, C., Kerwan, A., Al-Jabir, A., \& Iosifidis, C. et al. (2020). The socio-economic implications of the coronavirus pandemic (COVID-19): A review. International Journal of Surgery, 78, 185-193. doi: 10.1016/j.ijsu.2020.04.018

Przepiorka, A. (2015). What makes successful entrepreneurs different in temporal and goal-commitment dimensions? Time \& Society. doi: 10.1007/s00482-020-00518-1

Pal, R., Torstensson, H., \& Mattila, H. (2014). Antecedents of organizational resilience in economic crises- an empirical study of Swedish textile and clothing SMEs. International Journal of Production Economics, 147, 410-428. doi: https://doi.org/10.1016/j.ijpe.2013.02.031

Roundy, P. (2019). Back from the brink: The revitalization of inactive entrepreneurial ecosystems. Journal Of Business Venturing Insights, 12, e00140. doi: 10.1016/j.jbvi. 2019.e00140

Ratten, V. (2020). Coronavirus (Covid-19) and entrepreneurship: cultural, lifestyle and societal changes. Journal Of Entrepreneurship in Emerging Economies, 13(4), 747-761. doi: 10.1108/jeee-06-2020-0163

Razak, M., Hidayat, M., Launtu, A., Putra, A. H. P. A. K., \& Bahasoan, S. (2020). Antecedents and consequence of brand management: empirical study of Apple's brand product. Journal of Asia Business Studies.

Sawalha, I. H. (2019). After the crisis: repairing a corporate image. Journal of Business Strategy. 
Shafie, D. I., \& Isa, S. M. (2021). Entrepreneur Resilience: How Do Entrepreneurial Self-Efficacy and Basic Psychological Needs Influence It? The Effect of COVID-19 on Malaysia's Small and Medium Enterprises. Jurnal Intelek, 16(2), 1-10.

Shepherd, D. A. (2020). COVID 19 and entrepreneurship: Time to pivot? Journal of Management Studies.

Sawalha, I. (2020). A contemporary perspective on the disaster management cycle. Foresight, 22(4), 469-482. doi: 10.1108/fs-11-2019-0097

Shepherd, D., Patzelt, H., \& Wolfe, M. (2011). Moving Forward from Project Failure: Negative Emotions, Affective Commitment, and Learning from the Experience. Academy Of Management Journal, 54(6), 12291259. doi: $10.5465 / \mathrm{amj} .2010 .0102$

Thielsch, M., Röseler, S., Kirsch, J., Lamers, C., \& Hertel, G. (2021). Managing Pandemics-Demands, Resources, and Effective Behaviours Within Crisis Management Teams. Applied Psychology, 70(1), 150187. doi: 10.1111/apps.12303

Thukral, E. (2021). COVID - 19: Small and medium enterprises challenges and responses with creativity, innovation, and entrepreneurship. Strategic Change, 30(2), 153-158.

van Praag, C., \& Versloot, P. (2007). What is the value of entrepreneurship? A review of recent research. Small Business Economics, 29(4), 351-382. doi: 10.1007/s11187-007-9074-x

Weekly operational update on COVID-19 - 6 September 2021. (2021). Retrieved 20 September 2021, from https://www.who.int/publications/m/item/weekly-operational-update-on-covid-19---6-september-2021

Williams, T., \& Shepherd, D. (2016). Building Resilience or Providing Sustenance: Different Paths of Emergent Ventures in the Aftermath of the Haiti Earthquake. Academy Of Management Journal, 59(6), 2069-2102. doi: 10.5465/amj.2015.0682

Williams, T., Gruber, D., Sutcliffe, K., Shepherd, D., \& Zhao, E. (2017). Organizational Response to Adversity: Fusing Crisis Management and Resilience Research Streams. Academy Of Management Annals, 11(2), 733769. doi: 10.5465/annals.2015.0134

World Health Organization Coronavirus Disease 2019 (COVID-19) Situation Report-97. Available from: https://www.who.int/docs/default-source/coronaviruse/situation-reports/20200426-sitrep-97-covid-19.pdf

Yunus, A.R. (2004). Personality congruence and compliance: A study among Students of a Higher Learning Institution in Sabah. Unpublished Fundamental Research Report. University Malaysia Sabah, Kota Kinabalu. 